\title{
Application of the FMEA concept to medical robotic system
}

\author{
Violeta Cristina DUMITRU ${ }^{1, a^{*}}$, Mirela CHERCIU ${ }^{2, b}$ \\ ${ }^{1}$ University of Craiova, Romania \\ ${ }^{2}$ University of Craiova, Romania \\ a*dumitru.violeta@yahoo.com, ${ }^{\text {b}}$ mirela_cherciu2005@yahoo.com
}

Keywords: FMEA, preventive quality, minimizing the risk

\begin{abstract}
This paper examines the potential risks for the design and manufacture products for medical robotics using FMEA method. So we researched all foreseeable potential defects and their causes and effects for a robotic arm. The product is decomposed into components / functions and researched on the requirements for construction, namely the preservation of these requirements during production. Through a qualitative assessment of the effect of a defect, the probability of occurrence and probability of detection were discovered risks and set appropriate corrective measures. Thus FMEA is an effective method of preventive quality assurance.
\end{abstract}

\section{Introduction}

FMEA method (Failure Mode and Effect Analysis) is a basic tool in project management, maintenance and total quality aimed to identifying potential causes of failure of products / processes and associated remedial actions. The appearance of this method takes place in the '60s in the U.S., linked to NASA projects. Later, the method starts to apply in the automotive industry in France. Recent trends in the evolution of the method are related to maintenance activities and quality assurance in small and medium enterprises. Technical products and systems failures are inevitable and will occur after a period of time. By definition, failure is the termination of the ability of a product / system to do the specific function [1]. The practice has shown that the costs to correct an undetected failure in an earlier stage increased 10 times from the implementation stage to another.

Companies are committed to manufacturing products that offer safety, without using materials / processes that could endanger customers or consumer environment. Therefore, it is a constant struggle to achieve zero defects (0 PPM) both in manufacturing and in services. So, this process must be measured and continuously improved. Firm competitive strategy is to prevent defects not detect them. To get maximum benefit by using this methodology, organizations need to ensure the full integration of FMEA in the management system and its application in the early stages of product development and processes.

\section{Mainstreaming project management}

Regarding the link between management and quality; much of the quality problems are caused not by technical level management. It is important that senior management is focused on quality. The main processes that give consistency Integrated Management concerns:

- development concept plan;

- implementation;

- quality control and evaluation.

Each entity (product, activity, process) the project must be measured. We choose measurable attributes, numerically quantified which are defining entity. Measurement is a function of performance on the track of the product. It compares attribute values with those of standard and rank. Here are some possible goals for designing a medical robotic system: to support and manipulate in 3D space instruments; lifting capacity and maintenance tasks in any position; ensure introduction / withdrawal robotic arm in a anatomically environment limit; to capture video images of the surgical field; security; to ensure dexterity of the end effector. Assessment and control 
activity is based on indicators of product / process. Output indicators are chosen so that we can determine the quality of the products obtained. In general, with the help of these indicators we can evaluate: execution precision; maintainability of the product; adaptability of the product to the change of the context. Process indicators are oriented towards determining the level of quality achieved as a consequence of a repeatable activity. With them are evaluated and certified activities achieve. Indicators used to define the quality of an activity / product:

(a) The efficiency to remedy the deficiencies (ERD)

$$
E R D=\frac{E}{E+D}
$$

where: E - represents errors / problems detected while performing the activity, D - defects found after the product was made.

(b) Density of deficiencies (DD)

$$
D D=\frac{E+D}{M}
$$

where: $\mathrm{E}$ and $\mathrm{D}$ are as defined above, and $\mathrm{M}$ represents the size of the product.

These indicators relate to the determination of resource efficiency, compliance schedule activities, their efforts in achieving the goals, how to handle unforeseen problems, how to solve the errors. Through a qualitative assessment of the effect of a defect, the probability of occurrence and probability of detection can be discovered the risks and set appropriate corrective measures. The FMEA is an effective method of preventive quality assurance.

\section{FMEA methodology}

FMEA analysis is done at the level of components (product, process). This analysis is to identify potential defects, the effects of these defects, the causes that can cause these defects and corrective actions that can prevent or eliminate the defects.

The defects are evaluated according to the following probabilities

$\mathrm{S}$ - severity level (severity);

$\mathrm{O}$ - frequency / probability of failure (occurrence);

$\mathrm{D}$ - error detection (detection).

Quantification of these probabilities is based on the score of 1-10. Based on this score, we calculate the Risk Priority Number (RPN) that characterizes the degree of risk to which it is subjected the product / process due to the defect in question. It covers all cases of failure. It is the product of three estimates: Severity $(\mathrm{S})$, occurrence $(\mathrm{O})$ and detection $(\mathrm{D})$ :

$$
\mathrm{RPN}=\mathrm{S} \times \mathrm{O} \times \mathrm{D}
$$

This number takes values between 0 and 1000. Defects with risk prioritization number (RPN) represent a danger for the product / process. In general, when the Risk Priority Number (RPN) is greater than 100 measures are needed to prevent potential failures. The purpose of any action taken is to reduce the probability of failure in the following order: Severity $(\mathrm{S})$, occurrence $(\mathrm{O})$ and detection (D). If the severity of $S=9 / 10$, it is necessary for the team to ensure that risk is offset by design or recommended actions. If the severity of $S=8 / 10$ or below, the team should consider the cases that have the highest values for $\mathrm{O}$ or $\mathrm{D}$. In general, it follows the prevention of these activities in order to reduce $\mathrm{O}$ (frequency / probability of failure) and is preferred corrective measures that have an impact on $\mathrm{D}$ (detection). 


\section{FMEA applied to medical robotic systems}

The robotic system studied consists of two subsystems, a robotic arm and an actuation system. Constructively, the robotic arm is composed of a large number of ball joints connected by short rigid links (vertebrae external / internal). Ensemble of two consecutive conjugate vertebrae is shown in Figure 1, and the landmark study, outer intermediate vertebra, Figure 2. The required technical conditions for the arm are: no corrosion, minimum abrasive wear (contact), lack of cracks, deformation, and breakage. The required technical conditions and technological for vertebra, are: there is no lack / surplus material; no flaking, cracks; no bubbles, scratches or other surface defects; uniform color; smooth surface; surface quality, $\mathrm{R}_{\mathrm{a}}=0,2 \mu \mathrm{m}$.

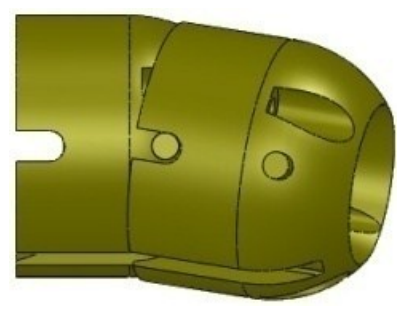

Fig. 1 Robotic arm assembly Consecutive vertebrae

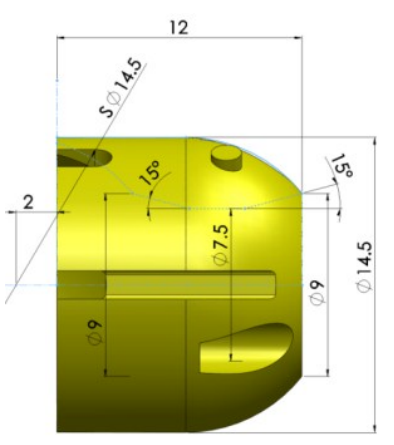

Fig. 2 Outer intermediate vertebra

Materials and technology. To achieve physical models were used printing techniques on EDEN $3503 \mathrm{D}$ printer (Figure 3) in the laboratory of innovative industrial technologies of the Transilvania University of Brasov. We used plastic photopolymer with the following properties: tensile strength 49.9 MPa; elongation - 15-25\%; modulus of elasticity - $2495 \mathrm{MPa}$; resistance to bending - 74.6 $\mathrm{MPa}$; specific density - 83.0 Shore. This material allows the weight reduction of the robot of up to 10 times and the construction in miniature.
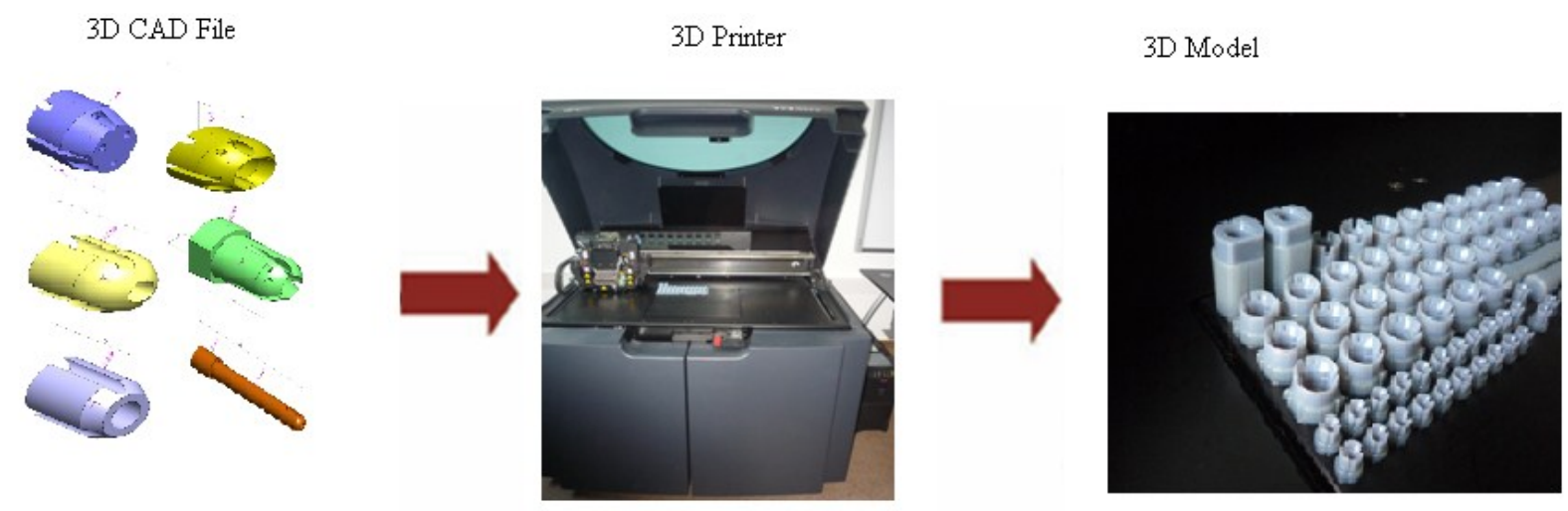

Fig. 3 Prototyping Printer 3D EDEN 350

Accuracy surfaces $(0,1-0,3 \mathrm{~mm})$ and roughness are adequate and the final pieces do not require further processing. In conclusion, we can say that elements using rapid prototyping technology are submitted in the rigors of shape and size, structure and time line [3].

Planning and preparation. FMEA analysis of product / process includes several stages: planning and preparation stage, risk analysis, risk assessment stage and stage risk minimization. At this stage, we analyzed the 3D printing plastic and simulated the process. The benchmarks were set to be analyzed FMEA, namely external vertebrae (proximal, intermediate, distal). We also collected the 
data on potential landmarks like the parts analyzed and potential consequences of defects in time and their importance to the customer. The 3D printing technology is very simple. Print head (inkjet dividers) pushes on a cooled platform the heated droplets of thermoplastic. They solidify and stick together, forming layers of the future object (print layers). The high quality of products made by 3D printing is due mainly to the following factors:

- contraction of the polymer;

- internal tensions of the printed product.

The contraction of the polymer can be minimized by heating the material to near its melting point; also the platform of construction has to be preheated. Internal stresses from the finished product are attenuated by deposit material as needed and where needed. Specific defective of the parts made by 3D printing: incomplete filling of the platform, burrs, deformation due to internal pressure, curly/exfoliated surface, thermal degradation, black bars, air gap.

Risk Analysis. In surgical robot cases, with general and specific functions (maintains and manipulates surgical instruments, safety operational, aesthetics) we added some specific functions that occur as a result of installation and operating conditions (convenience in handling, requires and allows passage of instruments from the first end (proximal) to the second end (distal) of the robotic arm. Operating conditions can be embedded in the mechanical system of the robotic arms if they are regarded as conventional systems composed of five elements, namely: material and technology; mating assembly; application tasks; anatomically environment sterilization. Regarding failure modes of the robotic arm for FMEA analysis can be considered the following defects: chemical etching; adhesion wear (contact); deformation; cracking or breaking.

Risk evaluation. At this stage all potential defects, potential consequences and potential causes of defects is assessed in relation to the potential importance of the defect, to the appearance and discovery probability of potential defects. Quantification of these probabilities was based on a scale from 1 to 10. Table 1 presents quantitative assessment of potential effect (severity) depending on the frequency.

Table 1 Quantitative assessment of severity

\begin{tabular}{|l|c|c|c|c|}
\hline \multirow{3}{*}{ Frequency } & \multicolumn{4}{|c|}{ Severity } \\
\cline { 2 - 5 } & 1 & 2 & 3 & 4 \\
\cline { 2 - 5 } & Minor & Moderate & Seriously & Disastrous \\
\hline Frequently & 7 & 8 & 9 & 10 \\
\hline & 6 & 7 & 8 & 9 \\
\hline Unlikely & 5 & 6 & 7 & 8 \\
\hline & 4 & 5 & 6 & 7 \\
\hline Isolated & 3 & 4 & 5 & 6 \\
\hline & 2 & 3 & 4 & 5 \\
\hline Extremely isolated & 1 & 2 & 3 & 4 \\
\hline
\end{tabular}

Table 2 FMEA Analysis for robotic system

\begin{tabular}{|c|c|c|c|c|c|}
\hline $\begin{array}{c}\text { Potential } \\
\text { failure } \\
\text { mode }\end{array}$ & $\begin{array}{c}\text { Potential } \\
\text { effects / } \\
\text { Severity } \\
\text { [S] }\end{array}$ & $\begin{array}{c}\text { Potential causes / } \\
\text { Probability of } \\
\text { occurrence } \\
{[0]}\end{array}$ & $\begin{array}{c}\text { Current controls } \\
\text { (Prevention / } \\
\text { Detection)/Probability } \\
\text { of discover } \\
{[D]}\end{array}$ & $R P N$ & $\begin{array}{l}\text { Corrective } \\
\text { actions }\end{array}$ \\
\hline \multirow[t]{2}{*}{$\begin{array}{l}\text { Chemical } \\
\text { corrosion }\end{array}$} & \multirow{2}{*}{$\begin{array}{l}\text { Scratches, } \\
\text { Vibration } \\
\text { (5) }\end{array}$} & $\begin{array}{l}\text { Chemical } \\
\text { composition (2) }\end{array}$ & Material analysis (5) & 50 & $\begin{array}{l}\text { Change of the } \\
\text { material }\end{array}$ \\
\hline & & $\begin{array}{l}\text { Water, corrosive } \\
\text { agents }(5)\end{array}$ & Agent analysis (4) & 100 & $\begin{array}{l}\text { Cleaning, } \\
\text { replacement }\end{array}$ \\
\hline Adhesion & Exfoliation, & $\begin{array}{l}\text { Chemical } \\
\text { Composition (2) }\end{array}$ & Material analysis (5) & 80 & $\begin{array}{l}\text { Material } \\
\text { change }\end{array}$ \\
\hline
\end{tabular}




\begin{tabular}{|c|c|c|c|c|c|}
\hline \multirow[t]{11}{*}{$\begin{array}{l}\text { usage } \\
\text { (contact) }\end{array}$} & \multirow{11}{*}{$\begin{array}{l}\text { vibration, } \\
\text { heating } \\
\quad(8)\end{array}$} & $\begin{array}{l}\text { Thermal } \\
\text { treatment (3) }\end{array}$ & Parts analysis (4) & 96 & $\begin{array}{l}\text { Correction } \\
\text { procedures }\end{array}$ \\
\hline & & Processing (2) & Measuring deviation(3) & 48 & $\begin{array}{l}\text { Checking } \\
\text { processing }\end{array}$ \\
\hline & & $\begin{array}{l}\text { Incorrect } \\
\text { installation (2) }\end{array}$ & Arm design (4) & 64 & $\begin{array}{l}\text { Recovery } \\
\text { installation }\end{array}$ \\
\hline & & Tightly fit (5) & Measurements arm (3) & 120 & Recovery fit \\
\hline & & $\begin{array}{l}\text { Stiffness too } \\
\text { small (3) }\end{array}$ & Checking stiffness (3) & 72 & $\begin{array}{l}\text { Change } \\
\text { configuration }\end{array}$ \\
\hline & & Form deviations (8) & $\begin{array}{l}\text { Measuring } \\
\text { deviations (2) }\end{array}$ & 128 & Change parts \\
\hline & & $\begin{array}{l}\text { Coaxial } \\
\text { deviations (6) }\end{array}$ & $\begin{array}{l}\text { Measuring } \\
\text { deviations (4) }\end{array}$ & 192 & Align parts \\
\hline & & Shocks (4) & Load verification (3) & 96 & $\begin{array}{l}\text { Remove shock } \\
\text { Redesign arm }\end{array}$ \\
\hline & & Solid parts (4) & $\begin{array}{l}\text { Environment } \\
\text { analysis (4) }\end{array}$ & 128 & Cleanup \\
\hline & & Water, agent (5) & Agent analysis (4) & 160 & $\begin{array}{l}\text { Cleanup, } \\
\text { replacement }\end{array}$ \\
\hline & & Heat (3) & $\begin{array}{l}\text { Temperature } \\
\text { measuring (4) }\end{array}$ & 96 & Remove source \\
\hline \multirow[t]{6}{*}{ Deformation } & \multirow{6}{*}{$\begin{array}{l}\text { Vibration } \\
\text { (6) }\end{array}$} & $\begin{array}{l}\text { Chemical } \\
\text { composition (2) }\end{array}$ & Material analysis (5) & 60 & $\begin{array}{l}\text { Change } \\
\text { material }\end{array}$ \\
\hline & & $\begin{array}{l}\text { Incorrect } \\
\text { installation (2) }\end{array}$ & Arm design (4) & 48 & $\begin{array}{l}\text { Recovery } \\
\text { installation }\end{array}$ \\
\hline & & Tightly fit (4) & $\begin{array}{l}\text { Dimension } \\
\text { measuring (6) }\end{array}$ & 144 & Part processing \\
\hline & & Load (8) & Load verification (6) & 288 & Load reduction \\
\hline & & Shocks (4) & Load verification (6) & 96 & $\begin{array}{l}\text { Shock } \\
\text { elimination }\end{array}$ \\
\hline & & Solid parts (5) & $\begin{array}{l}\text { Environment } \\
\text { analysis (5) }\end{array}$ & 150 & Cleanup \\
\hline \multirow{6}{*}{$\begin{array}{l}\text { Cracking / } \\
\text { breaking }\end{array}$} & \multirow{6}{*}{$\begin{array}{l}\text { Vibration } \\
\text { (4) }\end{array}$} & $\begin{array}{l}\text { Chemical } \\
\text { composition (2) }\end{array}$ & Material analysis (5) & 40 & $\begin{array}{l}\text { Change } \\
\text { material }\end{array}$ \\
\hline & & $\begin{array}{l}\text { Thermal } \\
\text { treatment (4) }\end{array}$ & Part analysis (2) & 32 & $\begin{array}{l}\text { Correction } \\
\text { procedures }\end{array}$ \\
\hline & & $\begin{array}{l}\text { Incorrect } \\
\text { installation (2) }\end{array}$ & Arm design (4) & 32 & $\begin{array}{l}\text { Recovery } \\
\text { installation }\end{array}$ \\
\hline & & Small fit (4) & $\begin{array}{l}\text { Dimension } \\
\text { measuring (6) }\end{array}$ & 96 & Part processing \\
\hline & & $\begin{array}{l}\text { Stiffness to } \\
\text { small (2) }\end{array}$ & $\begin{array}{l}\text { Stiffness } \\
\text { verification (6) }\end{array}$ & 48 & $\begin{array}{l}\text { Change } \\
\text { configuration }\end{array}$ \\
\hline & & Shocks (4) & Load verification (4) & 64 & $\begin{array}{l}\text { Shocks } \\
\text { elimination }\end{array}$ \\
\hline
\end{tabular}

After processing the information for the robotic arm system presented, their possible functions and failure modes in conditions imposed, was made a FMEA analysis, presented in Table 2. Risk of prioritization number (RPN) was obtained from the multiplication factors determined by the severity rating $(\mathrm{S})$, the probability of occurrence $(\mathrm{O})$ and the probability of discovery (D). For example, adhesion wear (contact), RPN $=8 \times 6 \times 4=192$.

RPN values in descending order for the subjected part to FMEA analysis are represented in the diagram in Figure 4. It can be seen that the various potential causes of failure, have different degrees of risk. Placing in the descending order of the scores RPN, potential causes of failure (Table 3) can emphasize with those that involve the greatest risk. 


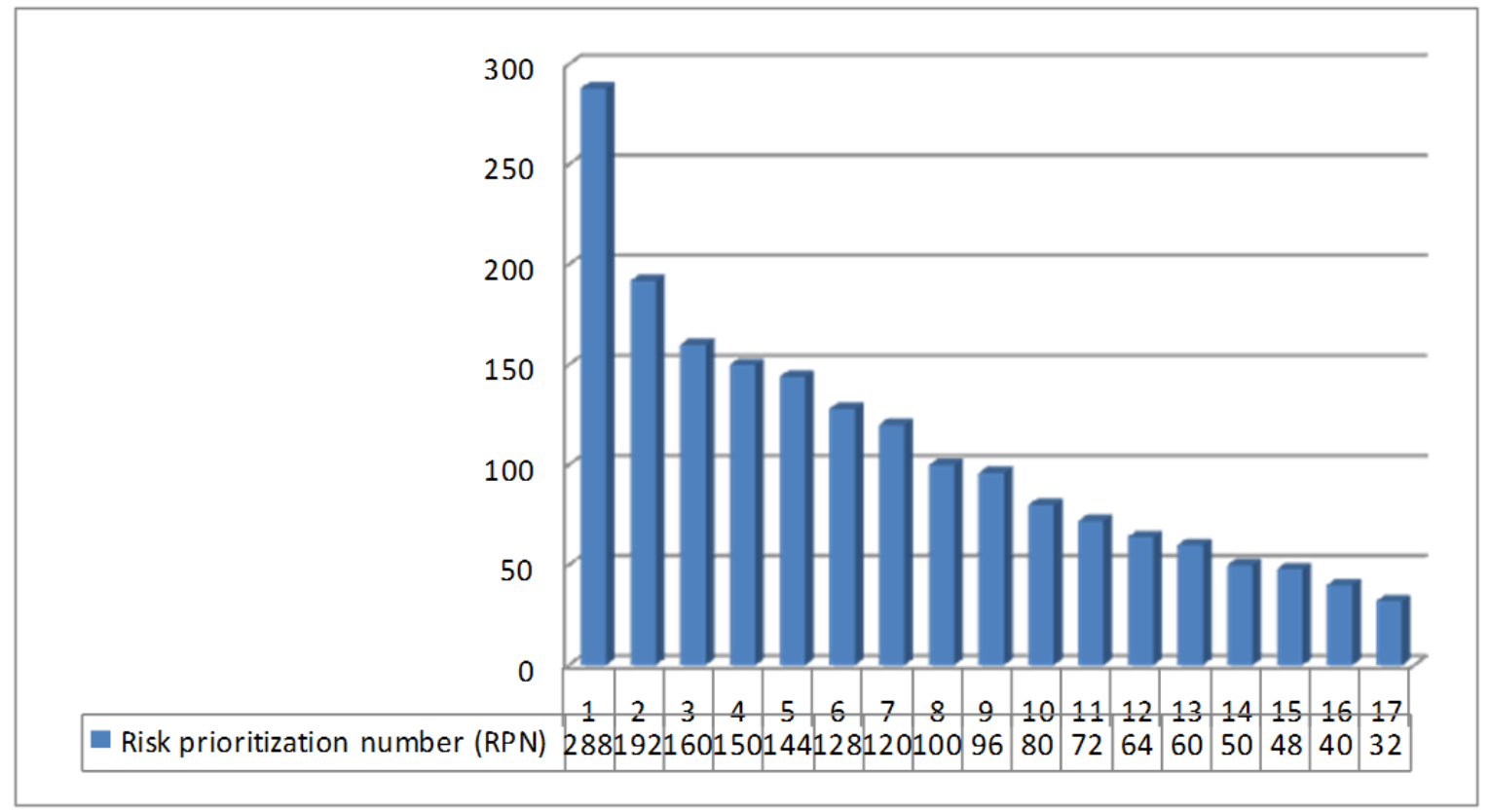

Fig. 4 Distribution diagram of the risk prioritization number (RPN)

Table 3 Potential causes of failure with higher risk

\begin{tabular}{|c|l|l|l|l|}
\hline No. & RPN & $\begin{array}{c}\text { Potential causes of } \\
\text { failure }\end{array}$ & \multicolumn{1}{|c|}{ Conventional element } & \multicolumn{1}{|c|}{ Failure mode } \\
\hline 1 & 288 & Big load & Applied load & Deformation \\
\hline 2 & 192 & Coaxial deviations & Joint parts assembly & Adhesion usage \\
\hline 3 & 160 & $\begin{array}{l}\text { Water, corrosive } \\
\text { agents }\end{array}$ & $\begin{array}{l}\text { Anatomically environment , } \\
\text { sterilization }\end{array}$ & Adhesion usage \\
\hline 4 & 150 & Solid parts & $\begin{array}{l}\text { Anatomically environment , } \\
\text { sterilization }\end{array}$ & Deformation \\
\hline 5 & 144 & Fit to tightly & Joint parts assembly & Deformation \\
\hline 6 & 128 & Deviation & Joint parts assembly & Adhesion usage \\
\cline { 3 - 5 } & Solid particles & $\begin{array}{l}\text { Anatomically environment , } \\
\text { sterilization }\end{array}$ & Adhesion usage \\
\hline 7 & 120 & Tightly fit & Joint parts assembly & Chemical corrosion \\
\hline 8 & 100 & $\begin{array}{l}\text { Water, corrosive } \\
\text { agent }\end{array}$ & $\begin{array}{l}\text { Anatomically environment , } \\
\text { sterilization }\end{array}$ & . \\
\hline
\end{tabular}

Conventional elements and failure modes with the highest risk, in descending order of risk are presented in Table 4. In both cases we consider the risk with maximum points.

Table 4 Ordering of conventional elements/ modes of failure according to the degree of risk

\begin{tabular}{|c|c|l|l|}
\hline No. & RPN & \multicolumn{1}{|c|}{ Conventional element } & \multicolumn{1}{|c|}{ Failure modes } \\
\hline 1 & 228 & Applied load & Deformation \\
\hline 2 & 192 & Joint parts assembly & Adhesion usage \\
\hline 3 & 160 & $\begin{array}{l}\text { Anatomically environment, } \\
\text { sterilization }\end{array}$ & Chemical corrosion \\
\hline 4 & 96 & Materials and technology & Cracking/breaking \\
\hline
\end{tabular}

It is found that the most probable failure modes for operation in the anatomic case are vibrations and blocking due to deformation and wear of adhesion (contact). Also, it can be seen that the most likely 
elements to cause damage when operating with robotic arms in anatomical environments are load task, assembling and environment.

Minimize the risk. From the distribution diagram of the number of risk prioritization (NPR) results that at defects that have RPN values over 150 are necessary corrective and preventive measures. Thus, for robotic arm with RPN $=288$ is recommended to reduce the applied loads. The result of this new risk indicates the effectiveness of measures taken.

\section{Conclusions}

FMEA is a method of analyzing and minimizing potential risks. With this method were investigated all potential defects and their causes and effects for a robotic arm. Thus, we identified opportunities to improve the design of the arm structure components in order to obtain an optimized model.

Operating conditions embodied in the mechanical arm are considered conventional systems composed of five elements, namely: material and technology; assembly parts; application tasks; anatomically environment; sterilization.

Regarding failure modes of robotic arms, for FMEA analysis were taken into account the following defects: chemical etching; adhesion wear (contact); deformation; cracking or breaking. For links (proximal, middle, and distal), the main analyzed defects are: mate spots, mate areas, surface scratches, flaking and strains.

We studied 26 potential causes of defects and have been proposed the following measures to improve: change material; cleaning, replacement of corrosive agent; verification and correction for procedures heat treatment; recovery installation; change and redesign robotic arm; removing the heat source; improve cooling arm; shock elimination.

\section{Acknowledgment}

This work was supported by the strategic grant POSDRU/159/1.5/S/133255, Project ID 133255 (2014), co-financed by the European Social Fund within the Sectorial Operational Program Human Resources Development 2007 - 2013

\section{References}

[1] Cross, N., Engineering design methods: strategies for product design, Wiley, 1994.

[2] Simaan, N., "High Dexterity Snake-like Robotic Slaves for Minimally Invasive Telesurgery of the Upper Airway," presented at MICCAI 2004 (7th International Conference on Medical Image Computing and Computer-Assisted Intervention), pp. 17-24, 2004.

[3] Udroiu, R., Ivan, N. V., Rapid prototyping and Rapid Manufacturing Applications at Transilvania University of Brasov, Bulletin of the Transilvania of Brasov, Vol. 3 (52) - 2010, Series I: Engineering Sciences.

[4] Bârsan, N., Defectarea. Modele statistice cu aplicatii. Ed. Economica., Bucureşti, 1999.

[5] Ţîţu, M., Fiabilitate şi mentenanţă, Editura AGIR, Bucureşti, 2009.

[6] Gerbu, T., Fiabilitatea si riscul instalatiilor. Elemente de teorie si calcul. Editura MatrixRom, Bucureşti, 2000.

[7] Birolini, A., Reliability Engineering.Theory and Practice, Springer, 2007.

[8] http://www.bccresearch.com/market-research/healthcare/robotics-computer-surgery-markethlc036d.html. 
[9] http://www.sbwire.com/press-releases/medical-robotics-market-global-industry-analysis-sizegrowth-share-and-forecast-2012-2018-166490.htm.

[10] *** Colecţia de Standarde în Domeniul Asigurării şi Managementului Calităţii.

[11] *** Ford Motor Company, General Motors Corporation. Potential Failure Modand Efects Analysis (FMEA), Reference, Manual, 1995. 